\title{
A DFT study of the NO dissociation on gold surfaces doped with transition metals
}

José L. C. Fajín, M. Natália D. S. Cordeiro, and José R. B. Gomes’

Citation: The Journal of Chemical Physics 138, 074701 (2013); doi: 10.1063/1.4790602

View online: http://dx.doi.org/10.1063/1.4790602

View Table of Contents: http://aip.scitation.org/toc/jcp/138/7

Published by the American Institute of Physics

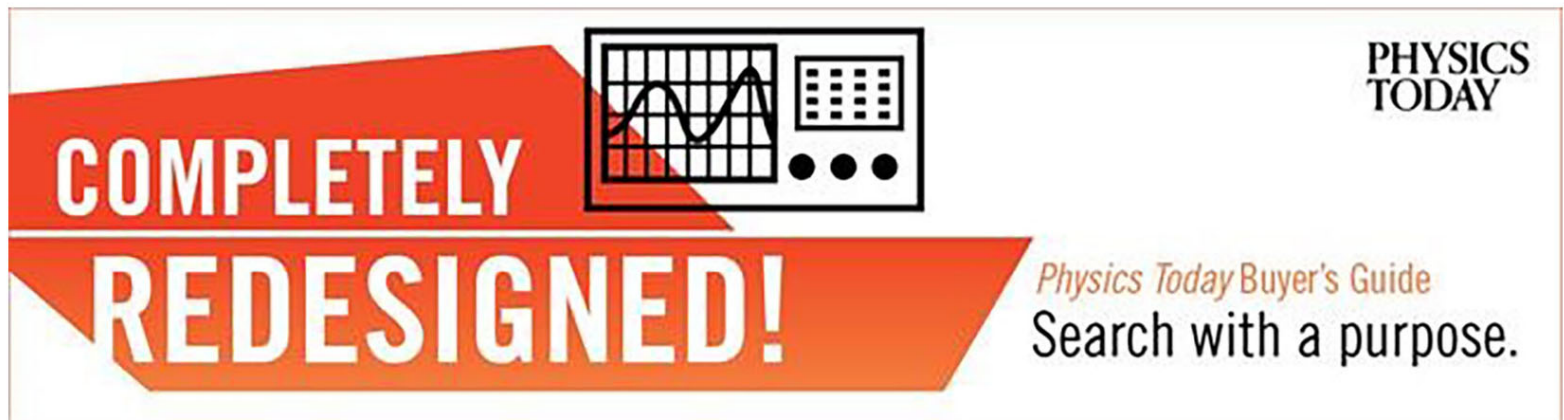




\title{
A DFT study of the NO dissociation on gold surfaces doped with transition metals
}

\author{
José L. C. Fajín, ${ }^{1}$ M. Natália D. S. Cordeiro, ${ }^{1}$ and José R. B. Gomes ${ }^{2, a)}$ \\ ${ }^{1}$ REQUIMTE, Faculdade de Ciências, Universidade do Porto, P-4169-007 Porto, Portugal \\ ${ }^{2}$ CICECO, Departamento de Química, Universidade de Aveiro, 3810-193 Aveiro, Portugal
}

(Received 11 September 2012; accepted 23 January 2013; published online 15 February 2013)

\begin{abstract}
The NO dissociation on a series of doped gold surfaces (type $\mathrm{TM}_{n} @ \mathrm{Au}(111)$ or $\mathrm{TM}_{n} @ \mathrm{Au}(110)$, with $\mathrm{TM}_{n}=\mathrm{Ni}$, Ir, Rh, or Ag and referring $n$ to the number of dopant atoms per unit cell) was investigated through periodic density functional theory calculations. Generally, doping of $\mathrm{Au}(111)$ and $\mathrm{Au}(110)$ matrices was found to strengthen the interaction with $\mathrm{NO}$ species, with the exception of $\mathrm{Ag}$, and was found to increase the energy barrier for dissociation, with the exception of $\mathrm{Ni}$ on $\mathrm{Au}(111)$. The calculations suggest that the NO dissociation is only possible in the case of the Ir@Au(110) bimetallic surface but only at high temperatures. The increase of the contents of $\operatorname{Ir}$ on $\mathrm{Au}(110)$ was found to improve significantly the catalytic activity of gold towards the NO dissociation $\left(E_{\text {act }}\right.$ $=\sim 1 \mathrm{eV}$ ). Nevertheless, this energy barrier is almost the double of that calculated for NO dissociation on pure $\operatorname{Ir}(110)$. However, mixing the two most interesting dopant atoms resulted in a catalyst model of the type Ir@Ni(110) that was found to decrease the energy barrier to values close to those calculated for pure Ir surfaces, i.e., $\sim 0.4 \mathrm{eV}$, and at the same time the dissociation reaction became mildly exothermic. () 2013 American Institute of Physics. [http://dx.doi.org/10.1063/1.4790602]
\end{abstract}

\section{INTRODUCTION}

The elimination of $\mathrm{NO}_{\mathrm{x}}$ species from the exhaust gas emissions is among the priorities nowadays due to the strong greenhouse effects of some of these gases, with the correspondent environmental implications. In particular, the nitrous oxide $\left(\mathrm{N}_{2} \mathrm{O}\right)$ has a warming potential 310 times larger than that of $\mathrm{CO}_{2}$ gas and 15 times larger than that of $\mathrm{CH}_{4},{ }^{1}$ reason why it was elaborated rigorous normative for the control of their emissions in the exhaust gas motor vehicles emissions. ${ }^{2}$ In the case of motor vehicles the elimination of these species is usually carried out through its reduction to $\mathrm{N}_{2}$ using the conventional three-way catalysts which presents $\mathrm{Pt}, \mathrm{Pd}$, and $\mathrm{Rh}$ in its active phase, ${ }^{3-5}$ being here a central reaction the NO reduction with $\mathrm{CO}\left(\mathrm{NO}+\mathrm{CO} \rightarrow \frac{1}{2} \mathrm{~N}_{2}+\mathrm{CO}_{2}\right)$ since these gases are among the main contaminants emitted by the motor vehicles. Furthermore, other catalysts based on noble metals dispersed on a support were also tested for the $\mathrm{NO}_{\mathrm{x}}$ elimination ${ }^{6,7}$ as those based on $\mathrm{Ru},{ }^{8} \mathrm{Rh},{ }^{9} \mathrm{Ir}^{10-12} \mathrm{Pd},{ }^{13-15}$ $\mathrm{Pt},{ }^{16-22} \mathrm{Au},{ }^{23-26} \mathrm{Ag},{ }^{27-30}$ and also on alloys of these metals with cheaper metals. ${ }^{8,9,20,22,31,32}$ In some cases the noble metal was successfully replaced by other elements. ${ }^{33-37}$ Two general methods are used for the elimination of the $\mathrm{NO}_{\mathrm{x}}$ species from the exhaust gas emissions employing solid catalysts, (i) the Selective Catalytic Reduction (SCR $)^{38}$ and (ii) the $\mathrm{NO}_{x}$ Storage-Reduction (NSR), ${ }^{39,40}$ respectively, used for stationary and for non-stationary $\mathrm{NO}_{\mathrm{x}}$ sources.

Concerning to the mechanism for the $\mathrm{NO}_{\mathrm{x}}$ reduction to $\mathrm{N}_{2}$, several routes were proposed depending on the intermediates observed in the course of the catalytic reactions, which are also dependent on experimental conditions and on

\footnotetext{
a) Author to whom correspondence should be addressed. Electronic mail: jrgomes@ua.pt. Telephone: +351 234401 423. Fax: +351 234401470.
}

the catalyst's nature. ${ }^{6,8,13,25,26}$ Formation of $\mathrm{N}_{2} \mathrm{O}$ during the $\mathrm{NO}_{\mathrm{x}}$ reduction reaction is also possible, and catalysts are optimized to minimize its formation, ${ }^{19,31,41,42}$ or its reduction to molecular nitrogen. ${ }^{10,17,29,43}$ One of the intermediates observed in the reduction of $\mathrm{NO}$ with $\mathrm{CO}$ is $\mathrm{NCO}$, suggesting $\mathrm{NO}$ dissociation followed by reaction of an $\mathrm{N}$ adatom with CO. Interestingly, the NCO intermediate was not observed during the $\mathrm{NO}$ adsorption on $\mathrm{Au} / \mathrm{TiO}_{2} ;{ }^{44-47}$ but the formation of dinitrosyl complexes attached to the same Au atom, e.g., $\mathrm{Au}(\mathrm{NO})_{2}$ species, either in the presence or in the absence of $\mathrm{CO},{ }^{44,45}$ was detected. This suggests that the energy required to cleave the $\mathrm{N}-\mathrm{O}$ bond is very high on $\mathrm{Au} / \mathrm{TiO}_{2}$ catalysts, which is in agreement with the results from the density functional theory (DFT) studies by Wang et al. ${ }^{48}$ for NO adsorption on the $\mathrm{Au}(111)$ surface. They correlated the formation of $(\mathrm{NO})_{2}$ dimers with the high activation energy barrier for the $\mathrm{NO}$ dissociation on $\mathrm{Au}(111)$ and suggested that the $(\mathrm{NO})_{2}$ dimers evolve to $\mathrm{N}_{2} \mathrm{O}$. Therefore, the cleavage of the $\mathrm{N}-\mathrm{O}$ bond seems to be the crucial step during the reaction of NO reduction. ${ }^{13,21,49-51}$

Vinod et al. ${ }^{52}$ considered the $\mathrm{Au}(310)$ surface model catalyst for investigating NO reduction on gold, concluding that the reaction mechanism based on bond dissociation of $\mathrm{NO}$ species is more plausible, which is surprising taking into account the high activation energy barrier $\left(E_{\text {act }}=\sim 3.9 \mathrm{eV}\right)$ associated to the reaction of $\mathrm{NO}$ dissociation on the $\mathrm{Au}(111)$ surface. ${ }^{48}$ This is a very large value, especially, when compared with the NO dissociation energy barriers on surfaces of more reactive metals such as $\operatorname{Ir}(100),{ }^{53} \mathrm{Rh}(111),{ }^{54}$ $\mathrm{Rh}(100),{ }^{55,56}$ or $\mathrm{Rh}(211),{ }^{54}$ surfaces, with $E_{\text {act }}=\sim 0.5 \mathrm{eV}$, $\sim 1.4 \mathrm{eV}, \sim 0.4 \mathrm{eV}$, and $\sim 0.7 \mathrm{eV}$, respectively. However, other factors, such as the presence of promoters on the catalytic surface, may have an important role in reducing the large activation energies associated with the cleavage of the $\mathrm{N}-\mathrm{O}$ 
bond on $\mathrm{Au}$ surfaces. We have found that $\mathrm{H}$ adatoms on the $\mathrm{Au}(321)$ model surface can react with $\mathrm{NO}$ and leads to a series of alternative reaction paths with concomitant lower activation energy barriers for the dissociation of the $\mathrm{N}-\mathrm{O}$ bond. ${ }^{57}$ Our findings are in agreement with previous experimental studies where it was found that the NO reduction on gold based catalysts at moderate temperatures started only if hydrogen species were available. ${ }^{51,58,59}$ All of these suggestions must be handled with caution since the reaction of NO dissociation, as other steps in the reaction of NO reduction, was found to be structure sensitive, ${ }^{21,50,60-67}$ i.e., is influenced by intrinsic specificities of the catalyst surfaces considered (e.g., special sites close to undercoordinated atoms).

A very recent exhaustive DFT study was devoted to the mechanism of the NO reduction by $\mathrm{CO}$ on gold based catalysts where several different reaction paths were considered on the clean or on the hydrogen covered $\mathrm{Au}$ (321) model surface. ${ }^{68}$ It was found that in the presence of $\mathrm{H}$ atoms on the catalyst surface, the reaction evolves through the $\mathrm{N}-\mathrm{O}$ bond break after successive hydrogenation reactions of NO. These reaction steps have to compete with the formation of $\mathrm{NH}_{3}$. If $\mathrm{H}$ species are not available on the catalyst surface, the reaction evolves through the $\mathrm{ON}_{2} \mathrm{O}$ and $\mathrm{N}_{2} \mathrm{O}$ intermediates. The dissociation of the $\mathrm{N}-\mathrm{O}$ bond in the $\mathrm{N}_{2} \mathrm{O}$ molecule leads to the formation of $\mathrm{N}_{2}$.

Herewith, we would like to understand if the reaction of $\mathrm{N}-\mathrm{O}$ bond dissociation is indeed possible on gold surfaces without the presence of adsorbates able to promote this reaction. This information is very important to understand the $\mathrm{NO}_{\mathrm{x}}$ reduction on gold based catalysts. Thus, the NO dissociation, a key step in the $\mathrm{NO}_{\mathrm{x}}$ reduction by noble metal based catalysts, ${ }^{13,21,49-51}$ is studied here on a series of doped $\mathrm{Au}(111)$ and $\mathrm{Au}(110)$ surfaces. The latter surface presents undercoordinated atoms and, upon comparison with the results for the flat $\mathrm{Au}$ (111) surface, will allow the understanding of the structure sensitivity of the NO dissociation reaction. The doped gold surfaces were obtained by substitution of one or two gold atoms in the topmost gold layer in a $(2 \times 2)$ unit cell by $\mathrm{Ni}, \mathrm{Ir}, \mathrm{Rh}$, or Ag atoms. The choice of the Ir and Rh doping elements is based on previous works where it was found that these elements are able to stabilize the adsorption of the reactants and to reduce the activation energies barriers for $\mathrm{N}-\mathrm{O}$ bond dissociation. ${ }^{53,54,69}$ The choice of the Ni (cheap metal) and $\mathrm{Ag}$ (frequent metal in catalysts) elements is also based on previous studies where it was found that these metals seem to be good catalysts for the dissociation of $\mathrm{O}-\mathrm{X}$ bonds $(\mathrm{X}=\mathrm{H}$, $\mathrm{N}$, or $\mathrm{O}) .^{70-72}$

\section{CATALYST SURFACE MODELS AND COMPUTATIONAL DETAILS}

\section{A. Slab models}

The reaction of NO dissociation was proposed to be a crucial step in the $\mathrm{NO}_{\mathrm{x}}$ reduction on gold based catalysts. ${ }^{49,51}$ Surfaces from transition metals such as $\mathrm{Ir}^{53}$ or $\mathrm{Rh}^{54-56}$ were found to be quite active for the reaction of NO dissociation. These two metals and also $\mathrm{Ag}$ and $\mathrm{Ni}$ will be used to replace

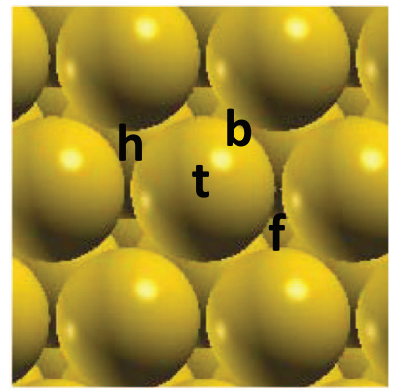

(a)

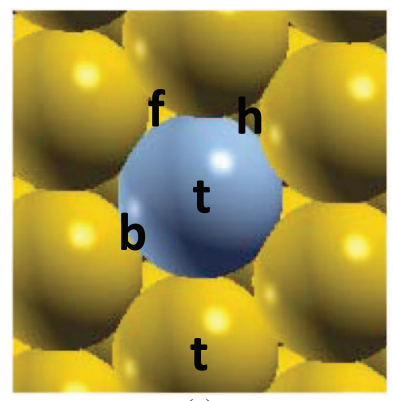

(c)

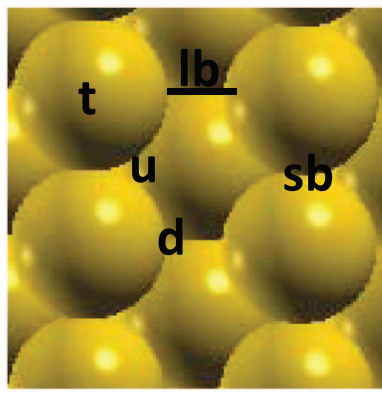

(b)

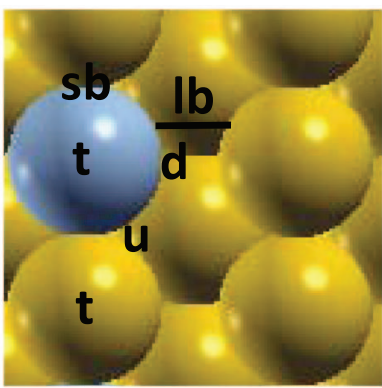

(d)
FIG. 1. Notation for the adsorption positions considered in the adsorption on the (a) Au(111), (b) Au(110), (c) TM@Au(111), and (d) TM@Au(110) surfaces. Yellow and blue spheres stand for Au and TM atoms, respectively. Adsorption sites are: b-bridge; d-hollow 3 (down); f-hollow fcc; hhollow hcp; lb-long-bridge; sb—short-bridge; $t$-top; $u$-hollow 3 (up).

$\mathrm{Au}$ atoms on $\mathrm{Au}(111)$ or $\mathrm{Au}(110)$ in order to understand if it is possible to improve the activity of gold towards the reduction of $\mathrm{NO}_{\mathrm{x}}$ by doping. The bimetallic surface models obtained are of the type $\mathrm{TM}_{n} @ \mathrm{Au}(111)$ or $\mathrm{TM}_{n} @ \mathrm{Au}(110)$, with $\mathrm{TM}=\mathrm{Ni}, \mathrm{Ir}, \mathrm{Rh}$, or Ag, and where $n$ refers to the number of atoms of the doping element per unit cell. The Au(111) surface is flat and is the most stable termination for gold while the $\mathrm{Au}(110)$ surface possesses low coordinated atoms, which are highly relevant to catalyze some reactions. Also important for supporting the choice of the $\mathrm{Au}(110)$ surface are the previous reports on the structural sensitivity of the reaction of $\mathrm{NO}_{\mathrm{x}}$ reduction on metallic catalysts. ${ }^{21,50,60-66}$ The (111) and (110) slab models used in this work consist of $2 \times 2$ unit cells with respect to the minimal unit cell and have a thickness of four metallic layers. ${ }^{73}$ The convergence of the results with the number of atomic layers in the slab was checked in previous works. ${ }^{71,73}$ Some gold atoms in the topmost layer of these surfaces were substituted by atoms of Rh or of Ir, or also by atoms of $\mathrm{Ni}$ (a cheap metal) or of $\mathrm{Ag}$ which is usually used for the elaboration of catalysts for the $\mathrm{NO}_{\mathrm{x}}$ elimination. ${ }^{27-30}$ In the case of the $\mathrm{Au}(110)$ surface, only Au atoms at the ridges (from now on named combs as in Ref. 71) were replaced by the dopant elements (see Figure 1). Bimetallic surfaces with higher concentration of dopant species per unit cell were also considered. In this case, two gold atoms were replaced by iridium resulting in the $\mathrm{Ir}_{2} @ \mathrm{Au}(110)$ model surface. Depending on the relative positions of the replaced atoms in the topmost layer of the $\mathrm{Au}(110)$ surface, three different combinations are possible for this doped surface (Figure 2). Doping with two Ir atoms at nearest-neighbor positions of adjacent combs results in the $\operatorname{Ir}_{\text {comb }} \operatorname{Ir}_{\text {comb }} @ \mathrm{Au}(110)$ surface model 


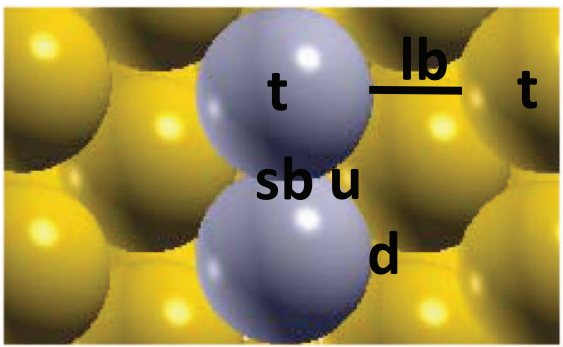

(a)

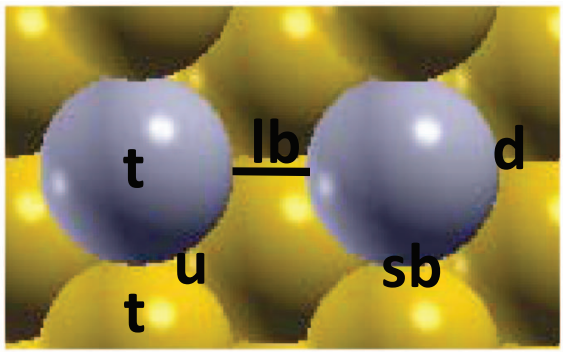

(b)

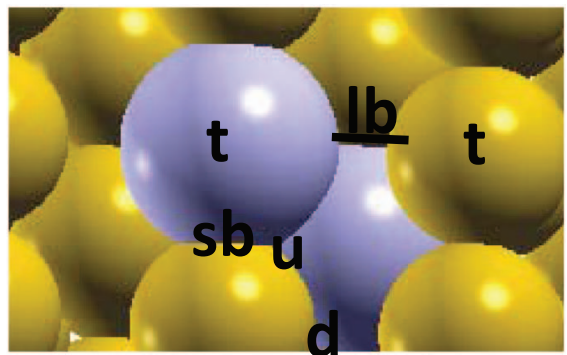

(c)

FIG. 2. Notation for the adsorption positions considered in the adsorption on the (a) $\operatorname{Ir}_{2, \text { comb }} @ A u(110)$, (b) $\operatorname{Ir}_{\text {comb }} \operatorname{Ir}_{\text {comb }} @ A u(110)$, and (c) $\mathrm{Ir}_{\mathrm{valley}} \mathrm{Ir}_{\mathrm{comb}} @ \mathrm{Au}(110)$ surfaces. Color code and adsorption site labeling as in Figure 1.

(Figure 2(a)), doping at the nearest-neighbor positions at the same comb results in the $\operatorname{Ir}_{2, \text { comb }} @ A u(110)$ surface model (Figure 2(b)) while doping at adjacent valley-comb positions yields the $\operatorname{Ir}_{\text {valley }} \mathrm{Ir}_{\text {comb }} @ \mathrm{Au}(110)$ surface model (Figure 2(c)). Other possible combinations of doping positions exist but the ones proposed above are those where at least one of the doping elements is at the more exposed comb sites, which in principle are those able to bind directly to the NO species and other possible adsorbates.

Since the metals above are very expensive, a bimetallic catalyst based on the $\mathrm{Ni}(110)$ surface was also considered in this work. Nickel was considered since it is cheaper than Ir, $\mathrm{Rh}, \mathrm{Au}$, or $\mathrm{Ag}$ and since it seems to have some activity towards the reaction of NO dissociation. ${ }^{70}$ The $\mathrm{Ni}(110)$ surface was doped with Ir atoms resulting in the Ir@ Ni(110) bimetallic model surface.

The optimized lattice constants for the bulk metals considered in this work were taken from previous works. ${ }^{57,74}$

The stabilities of the different bimetallic surfaces are conditioned by the relative concentration of each metal and by the temperature but they can be also dependent on the nature of the adsorbates. ${ }^{75}$ These parameters are relevant to deter- mine the tendency of metal pairs to mix at the catalyst surface or to assist the diffusion of the admetal into the bulk system, i.e., the surface composition of a transition-metal alloy is very sensitive to the external conditions of the experiment. ${ }^{76}$ Even if the dissolution of the admetal into the bulk is favorable, this dissolution will dependent on the global thermodynamic equilibrium which may not be established immediately for kinetic reasons. ${ }^{77}$ In general, the bimetallic surfaces considered in this work are stable but segregation may be affected by several different factors as referred above and its influence on the bimetallic catalysts considered here is difficult to be ascertained.

\section{B. DFT calculations}

The energies and geometries of the most stable configurations for the NO adsorption (reaction initial state, IS) and N + O pair co-adsorption (reaction final state, FS) on the bimetallic surface models presented above were obtained through minimization of the calculated energy with respect to the geometry. Spin-polarized DFT calculations were carried out using the VASP 5.2 computer code. ${ }^{78-80}$ All the calculations considered the PW91 generalized gradient approach (GGA) exchange correlation potential, ${ }^{81}$ the projected augmentedwave (PAW) method as implemented in VASP ${ }^{82,83}$ to take into account the effect of core electrons in the valence electron density, a cutoff of $415 \mathrm{eV}$ for the plane waves expansion and a $7 \times 7 \times 1$ Monkhorst-Pack grid of special k-points ${ }^{84}$ for the numerical integration in the reciprocal space. The convergence of the results with respect to the cutoff and to the Monkhorst-Pack grid was checked in previous works. ${ }^{57,71}$

The search of the transition state (TS) structures for the NO dissociation on the doped surface models was carried out using the Dimer approach ${ }^{85}$ and considering convergence criteria of $10^{-6} \mathrm{eV}$ for the total energy change and $10^{-3} \mathrm{eV} / \AA$ for the forces acting on the ions. The TS structures obtained were confirmed by checking the movement associated with the imaginary frequency.

The adsorption energies, the energy barriers (energy different between the transition and initial states), and reaction energy (energy difference between the initial and final states) were corrected with the zero point vibrational energy (ZPVE) correction, considering the harmonic oscillator approach.

The rate constants $(k)$ for the NO dissociation on the different surfaces were determined, according to the transition state theory, from the zero point vibrational corrected energy barriers and from the vibrational frequencies of the initial and transition states following Eq. (1):

$$
k=\left(\frac{k_{\mathrm{B}} T}{h}\right)\left(\frac{q^{\neq}}{q}\right) e^{\frac{-E_{\mathrm{a}}}{k_{\mathrm{B}} T}},
$$

where $k_{\mathrm{B}}$ is the Boltzmann constant, $T$ is the absolute temperature, $h$ is the Planck constant, and $E_{\mathrm{a}}$ is the activation energy from the ZPVE corrected calculated energy barrier. ${ }^{86}$ In Eq. (1), $q^{\neq}$and $q$ are the vibrational partition functions for the transition and initial states, respectively, which have been approximated from the harmonic vibrational frequencies. The vibrational frequencies were computed numerically allowing the complete relaxation of all atoms except those from the 
TABLE I. Adsorption energies $\left(E_{\mathrm{ads}}, \mathrm{eV}\right)$ and distances $(\mathrm{d}, \AA)$ for the adsorption of NO on several metallic and bimetallic surfaces.

\begin{tabular}{|c|c|c|c|c|c|}
\hline Surface & Adsorption site & $E_{\text {ads }}^{\mathrm{e}}$ & $E_{\mathrm{ads}}^{\mathrm{o}}{ }^{\mathrm{a}}$ & $\mathrm{d}_{\mathrm{N} \text {-surf }}{ }^{\mathrm{b}}$ & $\mathrm{d}_{\mathrm{N}-\mathrm{O}^{\mathrm{c}}}$ \\
\hline $\operatorname{Au}(111)^{\mathrm{d}}$ & Top & -0.59 & -0.57 & $2.21(\mathrm{Au})$ & 1.17 \\
\hline $\mathrm{Ni@Au(111)}$ & Top Ni & -1.86 & -1.81 & $1.68(\mathrm{Ni})$ & 1.17 \\
\hline Ir@Au(111) & Top Ir & -2.86 & -2.79 & $1.76(\mathrm{Ir})$ & 1.18 \\
\hline Rh@Au(111) & Top Rh & -2.38 & -2.34 & $1.78(\mathrm{Rh})$ & 1.17 \\
\hline Ag@Au(111) & Top Au & -0.37 & -0.36 & $2.23(\mathrm{Au})$ & 1.18 \\
\hline $\operatorname{Au}(110)$ & Short bridge & -0.53 & -0.50 & $2.24(\mathrm{Au}) ; 2.24(\mathrm{Au})$ & 1.19 \\
\hline $\mathrm{Ni@Au(110)}$ & Top Ni & -2.16 & -2.12 & $1.66(\mathrm{Ni})$ & 1.17 \\
\hline $\mathrm{Ir} @ \mathrm{Au}(110)$ & Top Ir & -3.32 & -3.26 & $1.76($ Ir) & 1.18 \\
\hline Rh@Au(110) & Top Rh & -2.70 & -2.66 & $1.77(\mathrm{Rh})$ & 1.17 \\
\hline Ag@Au(110) & Short bridge $\mathrm{Ag}-\mathrm{Au}$ & -0.48 & -0.45 & $2.32(\mathrm{Ag}) ; 2.11(\mathrm{Au})$ & 1.19 \\
\hline $\mathrm{Ir}_{2, \mathrm{comb}} @ \mathrm{Au}(110)$ & Short bridge (Ir-Ir) & -3.65 & -3.59 & $1.95(\mathrm{Ir}) ; 1.95(\mathrm{Ir})$ & 1.22 \\
\hline $\mathrm{Ir}_{\text {comb }} \mathrm{Ir}_{\mathrm{comb}} @ \mathrm{Au}(110)$ & Long bridge (Ir-Ir) & -3.67 & -3.61 & $1.82(\mathrm{~N}-\mathrm{Ir}) ; 2.08(\mathrm{O}-\mathrm{Ir})$ & 1.24 \\
\hline $\mathrm{Ir}_{\text {valley }} \mathrm{Ir}_{\text {comb }} @ \mathrm{Au}(110)$ & Top Ir & -2.93 & -2.86 & $1.77(\mathrm{Ir})$ & 1.18 \\
\hline Ir@Ni(110) & Top Ir & -2.81 & -2.75 & $1.78(\mathrm{Ir})$ & 1.19 \\
\hline
\end{tabular}

${ }^{\mathrm{a}}$ In $E_{\text {ads }}$ the labels e and o stand for uncorrected and zero point vibrational energy corrected adsorption energies.

${ }^{\mathrm{b}}$ Distances from the nitrogen atom to the nearest metal atoms on the surface.

${ }^{\mathrm{c}} \mathrm{N}-\mathrm{O}$ bond length.

${ }^{\mathrm{d}}$ Results taken from Ref. 87.

surface and farthest from the adsorbate which were already fixed in the optimization runs. Three different temperatures, e.g., $60 \mathrm{~K}, 470 \mathrm{~K}$, and $600 \mathrm{~K}$, were considered in the calculations in order to analyze the effect of the temperature in the rate constant values. ${ }^{68}$

\section{RESULTS}

The results calculated for the adsorption of $\mathrm{NO}$, for the co-adsorption of $\mathrm{N}$ and $\mathrm{O}$ adatoms, and for the reaction of NO decomposition on the different bimetallic model surfaces are described and analyzed in Subsections III A and III B.

\section{A. Adsorption of $\mathrm{NO}$ and co-adsorption of $\mathrm{N}+\mathrm{O}$}

Different initial configurations were considered in the study of the adsorption of $\mathrm{NO}$ and the co-adsorption of $\mathrm{N}$ and $\mathrm{O}$ adatoms on the different bimetallic surfaces. The initial configurations consider the interaction of the adsorbates with positions close to and far from the dopant atoms in the catalyst surface, in order to obtain the most favorable positions for the interaction of these adsorbates with the bimetallic surfaces. The final energies and geometries were obtained from these different initial structures, upon full optimization of the coordinates of the adsorbates constituting atoms and of the uppermost transition metal atoms in the catalyst model.

The adsorption energy $\left(E_{\mathrm{ads}}\right)$ for the NO molecule on these surfaces was calculated as

$$
E_{\mathrm{ads}}=E_{\text {slab-NO }}-E_{\text {slab }}-E_{\mathrm{NO}},
$$

where $E_{\text {slab }}$ refers to the electronic energy of the metallic or bimetallic surface slab model, $E_{\mathrm{NO}}$ refers to the electronic energy of NO in the gaseous phase, and $E_{\text {slab-NO refers to the }}$ electronic energy of the slab-NO supersystem, while the co- adsorption energy for the $\mathrm{N}+\mathrm{O}$ pair was calculated as

$$
E_{\text {co-ads }}=E_{\text {slab-(N+O) }}-E_{\text {slab }}-E_{\mathrm{NO}}
$$

where $E_{\text {slab-(N+O) }}$ refers to the electronic energy of the supersystem composed by the slab model with the co-adsorbed $\mathrm{N}$ and $\mathrm{O}$ species. According to these equations, negative values of $E_{\text {ads }}\left(E_{\text {co-ads }}\right)$ mean favorable adsorption (co-adsorption) with respect to the energy of NO in the gas phase. These adsorption and co-adsorption energies were corrected with the zero point vibrational energy correction.

The numeric results for the most favorable NO adsorption configuration on each surface are presented in Table I while views of the optimized structures are shown in Figure 3. As it can be seen for all the TM@Au(111) and TM@Au(110) surfaces studied (see Figure 1), with $\mathrm{TM}=\mathrm{Ni}$, Ir, Rh, Ag, or $\mathrm{Au}$, the NO adsorption is more favorable when the NO interacts with the surface through its nitrogen atom and, with the exception of the NO adsorption on the Ag@Au(111) surface, the NO interacts preferably with the dopant atom. In the case of the Ag@Au(111) surface, the NO molecule sits above an $\mathrm{Au}$ atom adjacent to the $\mathrm{Ag}$ dopant. The results show also that the most favorable adsorption site for the NO species on these surfaces is a top site with the exception of the Ag@ $\mathrm{Au}(110)$ and $\mathrm{Au}(110)$ surfaces for which a bridge position is preferred.

The NO adsorption energy varies from moderate values calculated for the pure gold surfaces, i.e., $-0.57 \mathrm{eV}^{87}$ ( $-0.15 \mathrm{eV}$ in Ref. 48) on $\mathrm{Au}(111)$ and $-0.50 \mathrm{eV}$ on $\mathrm{Au}(110)$, or on the $\mathrm{Ag}$ doped gold surfaces, i.e., $-0.36 \mathrm{eV}$ on the $\mathrm{Ag} @ \mathrm{Au}(111)$ surface and $-0.45 \mathrm{eV}$ on the $\mathrm{Ag} @ \mathrm{Au}(110)$ surface, to high adsorption energy values as that calculated for NO interaction with the Ir@Au(110) surface (value of $-3.26 \mathrm{eV}$ ). Adsorption energies more negative than $-2.0 \mathrm{eV}$ were also calculated for $\mathrm{Ni}$ and $\mathrm{Rh}$ doped Au surfaces. Therefore, the doping of gold surfaces with atoms of $\mathrm{Ir}, \mathrm{Ni}$, and $\mathrm{Rh}$ has a strong effect in the stabilization of the NO adsorption on gold surfaces, with very high adsorption energies. The comparison of data calculated for the doped surfaces suggests a 

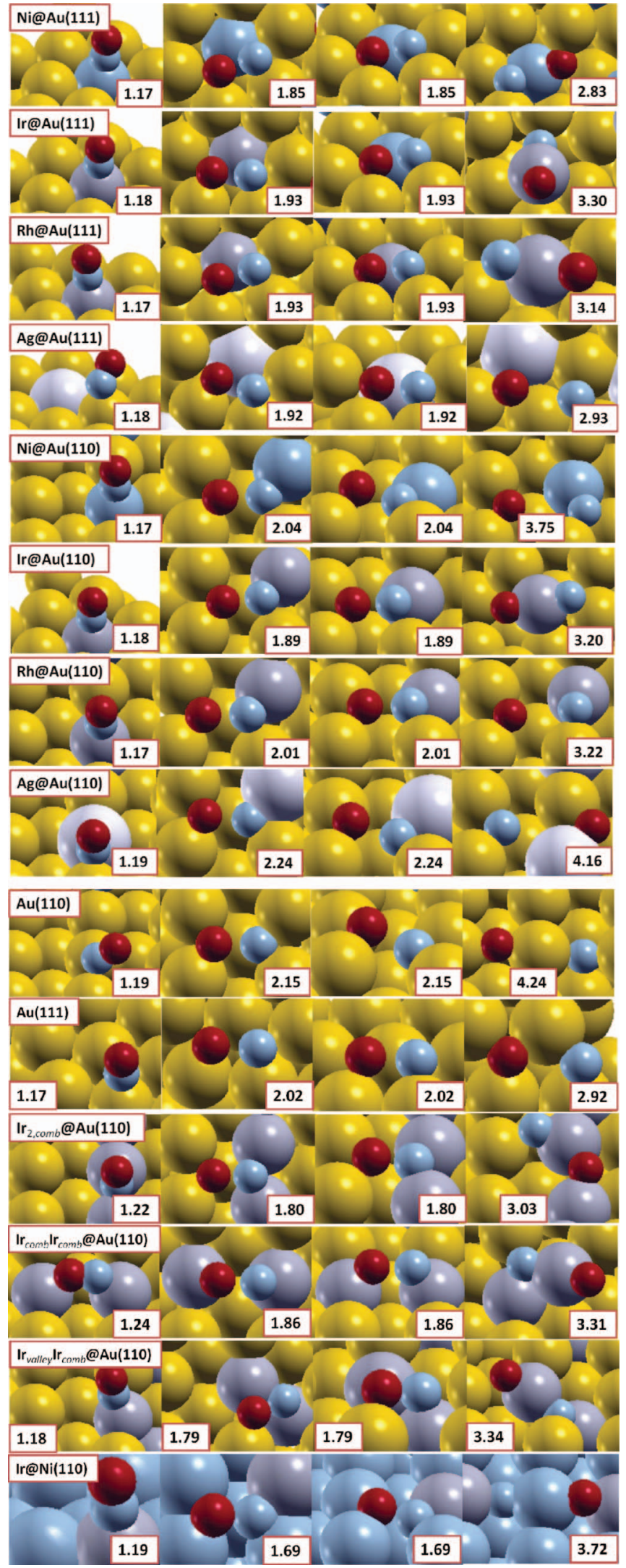

FIG. 3. Optimized structures for the initial (IS, leftmost panels), transition (TS, two central panels), and final (FS, rightmost panels) states for the NO $\rightarrow \mathrm{N}+\mathrm{O}$ most favorable reaction path on a series of metallic and bimetallic surfaces. Length of the cleaved $\mathrm{N}-\mathrm{O}$ bond is given in $\AA$. rather local character for the NO-surface interaction. For instance, the calculated adsorption energies for NO on pure Ir surfaces are of about $3.0 \mathrm{eV},{ }^{69}$ which is not far from the calculated energies for NO on Ir@Au(111), $E_{\text {ads }}=-2.79 \mathrm{eV}$ and on Ir@Au(110), $E_{\mathrm{ads}}=-3.26 \mathrm{eV}$.

Strong adsorption energies for NO on metal surfaces are very important for stabilizing this molecule on the catalyst surfaces benefiting the dissociation of $\mathrm{N}-\mathrm{O}$ bond prior to the occurrence of NO desorption. Obviously, the corresponding activation energy barriers on the catalyst surfaces must be smaller, in absolute values, than the adsorption energies.

For the most favorable case with just one dopant atom in the unit cell, i.e., for Ir@ $\mathrm{Au}(110)$, a second Ir atom was introduced for checking the effects of increasing the concentration of the dopant element in the catalysis of the NO dissociation reaction. As it can be seen in the lower rows of Table I, when the two Ir atoms are at comb sites (Figure 2), the interaction energy of NO with the bimetallic surface increases by $\sim 0.25 \mathrm{eV}$ with respect to the $\mathrm{Ir} @ \mathrm{Au}(110)$ surface. Entry of the second Ir atom at a valley site (Figure 2) has an opposite effect and the calculated energy is diminished by $\sim 0.4 \mathrm{eV}$ with respect to the Ir@ Au(110) surface. Interestingly, in the most stable cases, i.e., for the $\operatorname{Ir}_{2, \mathrm{comb}} @ \mathrm{Au}(110)$ and $\mathrm{Ir}_{\text {comb }} \mathrm{Ir}_{\mathrm{comb}} @ \mathrm{Au}(110)$ surfaces, the adsorption of NO occurs on a bridge site while for the least stable case, i.e., for the $\mathrm{Ir}_{\text {valley }} \mathrm{Ir}_{\text {comb }} @ \mathrm{Au}(110)$ surface, the adsorption occurs on a top position above the outermost Ir atom. Thus, in the former cases, the interaction occurs with two dopant species while in the latter case it occurs directly with just one Ir atom.

Finally, the comparison of the adsorption energies on the (111) and (110) Miller indices shows that the interaction is always stronger in the latter (including some low coordinated surface atoms) than in the former. The smaller variation occurs for the Ag doped surfaces $(0.09 \mathrm{eV})$ and the largest one is found for the Ir doped surfaces $(0.47 \mathrm{eV})$.

The results calculated for the interaction of the NO species with a catalyst model built from Ir atoms inlayed on a much cheaper matrix than the gold surfaces considered above, e.g., the Ni(110) surface, are also shown in Table I. The calculated interaction energy is $-2.75 \mathrm{eV}$ for $\mathrm{NO}$ interacting on top with the dopant species. The N-surface and $\mathrm{N}-\mathrm{O}$ distances are similar to those calculated for the Ir@Au surfaces.

The interaction energies and selected distances for the simultaneous interaction of $\mathrm{N}$ and $\mathrm{O}$ atom with the bimetallic surfaces considered for the adsorption of the NO species are presented in Table II (most favorable configurations). In general, the $\mathrm{N}$ and $\mathrm{O}$ atoms are preferentially co-adsorbed on hollow or on bridge positions as found on other metallic surfaces. ${ }^{57,74}$ The co-adsorption energies are very negative when the surfaces are doped with Ir atoms (values up to $-3.89 \mathrm{eV}$ ) being the most stable case the $\mathrm{Ir}_{2, \text { comb }} @ \mathrm{Au}(110)$ surface. A very similar co-adsorption energy $\left(E_{\mathrm{co}-\text { ads }}=-3.60\right.$ eV) was calculated for the Ir@Ni(110) surface. Negative but very close to zero energies were calculated for coadsorption of $\mathrm{N}$ and $\mathrm{O}$ atoms on the Rh@Au(110) and on the

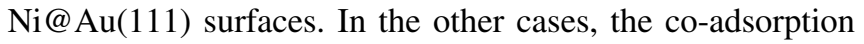
energies are always positive.

The energetic data in Table II suggest stabilization of the $\mathrm{N}$ and $\mathrm{O}$ adatoms on gold based surfaces when these 
TABLE II. Co-adsorption energies $\left(E_{\mathrm{ads}}, \mathrm{eV}\right)$ and distances $(\mathrm{d}, \AA)$ for the co-adsorption of $\mathrm{N}+\mathrm{O}$ on several metallic and bimetallic surfaces.

\begin{tabular}{|c|c|c|c|c|c|}
\hline Surface & Adsorption site N/O & $E_{\text {ads }}^{\mathrm{e}}$ & $E_{\text {ads }}^{\mathrm{o}} \mathrm{a}$ & $\mathrm{d}_{\mathrm{N} \text {-surf }}{ }^{\mathrm{b}}$ & $\mathrm{d}_{\mathrm{O} \text {-surf }}{ }^{\mathrm{c}}$ \\
\hline $\mathrm{Au}(111)$ & Hollow fcc/hollow fcc & 2.27 & 2.30 & $2.02(\mathrm{Au}) ; 2.02(\mathrm{Au}) ; 2.10(\mathrm{Au})$ & $2.05(\mathrm{Au}) ; 2.05(\mathrm{Au}) ; 2.25(\mathrm{Au})$ \\
\hline $\mathrm{Ni@Au(111)}$ & Hollow hcp/hollow fcc & -0.07 & -0.03 & $1.75(\mathrm{Ni}) ; 2.08(\mathrm{Au}) ; 1.97(\mathrm{Au})$ & $1.82(\mathrm{Ni}) ; 2.04(\mathrm{Au}) ; 2.19(\mathrm{Au})$ \\
\hline $\mathrm{Ir} @ \mathrm{Au}(111)$ & Bridge/top Ir & -1.16 & -1.15 & $2.07(\mathrm{Au}) ; 1.73(\mathrm{Ir})$ & $1.74(\mathrm{Ir})$ \\
\hline Rh@Au(111) & Hollow fcc/hollow hcp & 0.06 & 0.08 & $1.79(\mathrm{Rh}) ; 2.14(\mathrm{Au}) ; 2.14(\mathrm{Au})$ & $1.90(\mathrm{Rh}) ; 2.27(\mathrm{Au}) ; 2.27(\mathrm{Au})$ \\
\hline Ag@Au(111) & Hollow fcc/hollow fcc & 2.11 & 2.14 & $2.03(\mathrm{Au}) ; 2.03(\mathrm{Au}) ; 2.08(\mathrm{Au})$ & $2.23(\mathrm{Ag}) ; 2.06(\mathrm{Au}) ; 2.06(\mathrm{Au})$ \\
\hline $\mathrm{Au}(110)$ & Hollow(3-down)/long bridge & 1.79 & 1.78 & $2.13(\mathrm{Au}) ; 2.13(\mathrm{Au}) ; 2.16(\mathrm{Au})$ & $2.09(\mathrm{Au}) ; 2.09(\mathrm{Au})$ \\
\hline $\mathrm{Ni@Au(110)}$ & Hollow(3-up)/hollow(3-up) & 0.58 & 0.58 & $1.70(\mathrm{Ni}) ; 2.05(\mathrm{Au}) ; 2.21(\mathrm{Au})$ & $2.08(\mathrm{Au}) ; 2.08(\mathrm{Au}) ; 2.37(\mathrm{Au})$ \\
\hline Ir@Au(110) & Long bridge/top Ir & -1.79 & -1.78 & $1.72(\mathrm{Ir}) ; 2.22(\mathrm{Au})$ & $1.76(\mathrm{Ir})$ \\
\hline Rh@Au(110) & Short bridge/hollow(3-up) & -0.04 & -0.03 & $1.73(\mathrm{Rh}) ; 2.07(\mathrm{Au})$ & $2.08(\mathrm{Au}) ; 2.07(\mathrm{Au}) ; 2.36(\mathrm{Au})$ \\
\hline Ag@Au(110) & Hollow(3-up)/hollow(3-up) & 1.81 & 1.82 & $2.04(\mathrm{Au}) ; 2.04(\mathrm{Au}) ; 2.16(\mathrm{Au})$ & $2.15(\mathrm{Ag}) ; 2.06(\mathrm{Au}) ; 2.32(\mathrm{Au})$ \\
\hline $\mathrm{Ir}_{2, \mathrm{comb}} @ \mathrm{Au}(110)$ & Long bridge/short bridge & -2.75 & -2.73 & $1.73(\mathrm{Ir}) ; 2.23(\mathrm{Ir})$ & $1.96(\mathrm{Ir}) ; 1.91(\mathrm{Ir})$ \\
\hline $\mathrm{Ir}_{\mathrm{comb}} \mathrm{Ir}_{\mathrm{comb}} @ \mathrm{Au}(110)$ & Long bridge/top Ir & -3.92 & -3.89 & 1.89(Ir); 1.86(Ir) & 1.74(Ir) \\
\hline $\mathrm{Ir}_{\text {valley }} \mathrm{Ir}_{\mathrm{comb}} @ \mathrm{Au}(110)$ & Hollow(3-up)/top Ir & -2.17 & -2.14 & $1.85(\mathrm{Ir}) ; 1.85(\mathrm{Ir}) ; 2.10(\mathrm{Au})$ & 1.79(Ir) \\
\hline $\mathrm{Ir} @ \mathrm{Ni}(110)$ & Hollow(3-down)/long bridge & -3.63 & -3.60 & $1.83(\mathrm{Ni}) ; 1.85(\mathrm{Ni}) ; 1.85(\mathrm{Ni})$ & $1.82(\mathrm{Ni}) ; 1.90(\mathrm{Ir})$ \\
\hline
\end{tabular}

${ }^{\mathrm{a}}$ In $E_{\text {ads }}$ the labels e and o stand for uncorrected and zero point vibrational energy corrected co-adsorption energies.

${ }^{\mathrm{b}}$ Distances from the nitrogen atom to the nearest metal atoms on the surface.

${ }^{\mathrm{c}}$ Distances from the oxygen atom to the nearest metal atoms on the surface.

are doped with $\mathrm{Rh}$, Ni but specially Ir atoms. Interestingly, doping with $\mathrm{Ag}$ leads to co-adsorption energies more positive than those calculated for the corresponding pure gold surfaces. Also, a different trend to that obtained for the NO adsorption on (111) and on (110) facets is found for the coadsorbed $\mathrm{N}$ and $\mathrm{O}$ species. Now, the co-adsorption energies on the (110) index are more negative than on the (111) facet just for the Ir and Rh doped surfaces and a contrary effect is found for the $\mathrm{Ag}$ and $\mathrm{Ni}$ doped surfaces. This is very probably due to the effect of the radical character of the atomic species which bind differently to the different transition metals.

The co-adsorption energies in Table II were calculated with respect to the energy of NO in the gas phase and, therefore, exothermic NO dissociation reactions are calculated for surfaces having co-adsorption energies more negative than the adsorption energies for NO molecule shown in Table I. This occurs just for the $\operatorname{Ir}_{\text {valley }} \mathrm{Ir}_{\text {comb }} @ \mathrm{Au}(110)$ and $\mathrm{Ir} @ \mathrm{Ni}(110)$ surfaces.

\section{B. Activation energy barriers and rate constants}

The most stable configurations determined for $\mathrm{NO}$ adsorption and $\mathrm{N}+\mathrm{O}$ co-adsorption on each surface (pure or bimetallic) were used in the search of the transition state structures for the reaction of NO dissociation. The calculated activation energies barriers, reaction energies, reaction rate constants, and length of the $\mathrm{N}-\mathrm{O}$ bond are presented in Table III while representations of the initial, transition, and final states are given in Figure 3.

In the case of the (111) Miller index, the doping of the $\mathrm{Au}(111)$ surface with the transition metal atoms considered in this work leads to an increase by $\sim 0.4 \mathrm{eV}$ of the activation energy barrier for the $\mathrm{NO} \rightarrow \mathrm{N}+\mathrm{O}$ reaction with respect to that for pure $\mathrm{Au}(111)$ in the cases of Ir, Rh, and $\mathrm{Ag}$ atoms. An opposite effect is found when the doping species is $\mathrm{Ni}$, with a concomitant decrease of the calculated energy barrier for NO dissociation of $\sim 0.3 \mathrm{eV}$. The activation energy calculated for the Ni@ $\mathrm{Au}(111)$ surface is $2.59 \mathrm{eV}$. In these four bimetallic model surfaces, the comparison of the calculated activation energy barriers with the adsorption energies for $\mathrm{NO}$ on the corresponding surfaces suggests that the reaction of NO dissociation will not occur in normal reaction conditions. Since the activation energies are higher than the NO adsorption energies, desorption of the undissociated species is expected to take place. Finally, the calculated reaction energies for the NO dissociation on these $\mathrm{TM}_{1} @ \mathrm{Au}(111)$ surfaces suggest also a strong endothermic process $\left(E_{\text {react }}>1.6 \mathrm{eV}\right)$. Thus, it is not surprising to find a low catalytic performance (low rate constants are calculated even at $600 \mathrm{~K}$ ) for the $\mathrm{NO}$ dissociation on the Au(111) and on the TM $\mathrm{TM}_{1} @ \mathrm{Au}(111)$ model surfaces considered.

In the case of the (110) Miller index, all the doped gold surfaces of the TM $\mathrm{TM}_{1} @ \mathrm{Au}(110)$ type show a poorer catalytic behavior than the pure Au(110) surface (Table III). The calculated barriers vary from $2.58 \mathrm{eV}$ in the case of Ag doping to $2.94 \mathrm{eV}$ in the case of $\mathrm{Ni}$ doping. In fact, the calculated energy barriers for single substitution with $\mathrm{Ni}, \mathrm{Ir}, \mathrm{Rh}$, or $\mathrm{Ag}$ atoms are always larger than the barrier calculated for NO dissociation on the pure $\mathrm{Au}(110)$ model surface $\left(E_{\text {act }}=2.45 \mathrm{eV}\right)$, which suggests a negative effect for doping of $\mathrm{Au}(110)$. Furthermore, the calculated energy barriers for NO dissociation on $\mathrm{TM}_{1} @ \mathrm{Au}(110)$ are larger than those calculated for the $\mathrm{TM}_{1} @ \mathrm{Au}(111)$ models except when TM is Ni. In this case, the barrier increases by approximately $0.3 \mathrm{eV}$. As discussed above for (111) Miller index surfaces, the reaction energies calculated for $\mathrm{Au}(110)$ and for $\mathrm{TM}_{1} @ \mathrm{Au}(110)$ model surfaces are also very positive $\left(E_{\text {react }}>1.4 \mathrm{eV}\right)$. The NO dissociation reaction is also an endothermic process with concomitant low rate constants at the three temperatures studied $(60 \mathrm{~K}, 470 \mathrm{~K}$, and $600 \mathrm{~K})$. However, from the comparison of the activation energy barrier values for the NO dissociation on the $\mathrm{TM}_{1} @ \mathrm{Au}(110)$ surfaces with the adsorption energy of the NO on the same surfaces leads to the conclusion that the reaction may be possible under special temperature and pressure conditions in the case of iridium doped gold catalysts. In fact, the calculated adsorption energy for NO on Ir@Au(110) 
TABLE III. DFT calculated parameters for NO dissociation on several metallic and bimetallic surfaces.

\begin{tabular}{|c|c|c|c|c|c|c|c|c|c|}
\hline Surface & $\mathrm{N} \cdots \mathrm{O}^{\mathrm{a}}$ & $E_{\mathrm{act}}^{\mathrm{e} \mathrm{b}}$ & $E_{\mathrm{act}}^{\mathrm{oc}}$ & $E_{\text {react }}^{\mathrm{e}}{ }^{\mathrm{d}}$ & $E_{\text {react }}^{\mathrm{o}}{ }^{\mathrm{e}}$ & $v_{i}^{\mathrm{f}}$ & $k(60 \mathrm{~K})^{\mathrm{g}}$ & $k(470 \mathrm{~K})^{\mathrm{g}}$ & $k(600 \mathrm{~K})^{\mathrm{g}}$ \\
\hline $\operatorname{Au}(111)$ & 2.02 & 2.93 & 2.92 & 2.10 & 2.14 & 379.2 & $3.34 \times 10^{-234}$ & $2.85 \times 10^{-19}$ & $2.23 \times 10^{-12}$ \\
\hline Ni@Au(111) & 1.85 & 2.65 & 2.59 & 1.79 & 1.79 & 468.3 & $2.34 \times 10^{-206}$ & $9.39 \times 10^{-16}$ & $1.24 \times 10^{-09}$ \\
\hline Ir@Au(111) & 1.93 & 3.36 & 3.28 & 1.69 & 1.65 & 421.8 & $1.09 \times 10^{-264}$ & $3.66 \times 10^{-23}$ & $1.99 \times 10^{-15}$ \\
\hline $\mathrm{Rh} @ \mathrm{Au}(111)$ & 1.93 & 3.33 & 3.27 & 2.44 & 2.42 & 453.2 & $2.27 \times 10^{-263}$ & $5.71 \times 10^{-23}$ & $2.86 \times 10^{-15}$ \\
\hline Ag@Au(111) & 1.92 & 3.37 & 3.33 & 2.48 & 2.49 & 435.2 & $3.60 \times 10^{-268}$ & $1.23 \times 10^{-23}$ & $8.36 \times 10^{-16}$ \\
\hline $\operatorname{Au}(110)$ & 2.15 & 2.49 & 2.45 & 2.32 & 2.29 & 194.8 & $1.02 \times 10^{-194}$ & $4.34 \times 10^{-14}$ & $2.77 \times 10^{-08}$ \\
\hline Ni@Au(110) & 2.04 & 3.00 & 2.94 & 2.73 & 2.70 & 236.3 & $2.31 \times 10^{-235}$ & $2.33 \times 10^{-19}$ & $1.97 \times 10^{-12}$ \\
\hline Ir@Au(110) & 1.89 & 2.88 & 2.79 & 1.53 & 1.48 & 368.6 & $8.26 \times 10^{-223}$ & $8.25 \times 10^{-18}$ & $3.12 \times 10^{-11}$ \\
\hline Rh@Au(110) & 2.01 & 2.98 & 2.91 & 2.66 & 2.63 & 257.4 & $1.61 \times 10^{-233}$ & $2.47 \times 10^{-19}$ & $1.82 \times 10^{-12}$ \\
\hline Ag@Au(110) & 2.24 & 2.62 & 2.58 & 2.29 & 2.27 & 174.9 & $6.71 \times 10^{-206}$ & $1.32 \times 10^{-15}$ & $1.70 \times 10^{-09}$ \\
\hline $\mathrm{Ir}_{2, \mathrm{comb}} @ \mathrm{Au}(110)$ & 1.80 & 2.06 & 1.98 & 0.90 & 0.86 & 459.6 & $2.89 \times 10^{-155}$ & $4.31 \times 10^{-09}$ & $2.22 \times 10^{-04}$ \\
\hline $\mathrm{Ir}_{\mathrm{comb}} \mathrm{Ir}_{\mathrm{comb}} @ \mathrm{Au}(110)$ & 1.86 & 1.02 & 0.95 & -0.25 & -0.28 & 340.7 & $1.29 \times 10^{-68}$ & $6.29 \times 10^{+02}$ & $1.31 \times 10^{+05}$ \\
\hline $\mathrm{Ir}_{\text {valley }} \mathrm{Ir}_{\text {comb }} @ \mathrm{Au}(110)$ & 1.79 & 2.26 & 2.19 & 0.76 & 0.72 & 251.9 & $5.72 \times 10^{-173}$ & $2.02 \times 10^{-11}$ & $3.20 \times 10^{-06}$ \\
\hline $\mathrm{Ir} @ \mathrm{Ni}(110)$ & 1.69 & 0.48 & 0.41 & -0.82 & -0.85 & 395.8 & $3.47 \times 10^{-23}$ & $2.61 \times 10^{+08}$ & $2.98 \times 10^{+09}$ \\
\hline
\end{tabular}

${ }^{\mathrm{a}} \mathrm{N}$. . O breaking bond in $\AA$.

${ }^{\mathrm{b}}$ Activation energy barrier in $\mathrm{eV}$

${ }^{\mathrm{c}} \mathrm{ZPVE}$ corrected activation energy barrier in $\mathrm{eV}$.

${ }^{\mathrm{d}}$ Reaction energy in eV.

${ }^{\mathrm{e}} \mathrm{ZPVE}$ corrected reaction energy in $\mathrm{eV}$.

${ }^{\mathrm{f}}$ Imaginary wave numbers

${ }^{\mathrm{g}}$ Reaction rate constant $\left(\mathrm{s}^{-1}\right)$ at the temperature indicated in parentheses.

is $-3.26 \mathrm{eV}$ while the activation energy barrier calculated for the reaction of $\mathrm{NO}$ dissociation on this surface is $2.79 \mathrm{eV}$.

The effect of concentration of the dopant atoms on gold was analyzed for the most favorable case found above, i.e., the Ir@Au(110) surface. This model was considered in subsequent work where a second gold atom was replaced by iridium. Three different possibilities were considered with two Ir atoms per unit cell, i.e., model surfaces with two Ir atoms in the same crest (comb sites), in adjacent crests or in adjacent sites on the crests, and on the valleys of the (110) surface as shown in Figures 2(a)-2(c), respectively. The most striking result is the decrease of the barriers calculated for the NO reaction when compared with the $\mathrm{Au}(110)$ surface for the three cases considered, i.e., the introduction of a second $\mathrm{Ir}$ atom is very favorable for the catalysis of the reaction. The decrease is small in the cases of $\operatorname{Ir}_{2, \text { comb }} @ \mathrm{Au}(110)$ and $\operatorname{Ir}_{\text {valley }} \operatorname{Ir}_{\text {comb }} @ \mathrm{Au}(110)$, i.e., gains of $0.47 \mathrm{eV}$ and $0.26 \mathrm{eV}$, respectively, but is very dramatic in the case of the $\mathrm{Ir}_{\text {comb }} \mathrm{Ir}_{\text {comb }} @ \mathrm{Au}(110)$ model surface. In the latter surface, the energy barrier is reduced by $1.50 \mathrm{eV}$ to only $0.95 \mathrm{eV}$. Nevertheless, even in this very favorable situation, the energy barrier is practically the double of that calculated for the NO dissociation on the pure $\operatorname{Ir}(110)$ surface for which a value of $0.46 \mathrm{eV}$ was calculated. ${ }^{53}$

The reaction of NO dissociation is found to be endothermic in the cases of the $\mathrm{Ir}_{2, \text { comb }} @ \mathrm{Au}(110), E_{\text {react }}=0.90 \mathrm{eV}$ and $\mathrm{Ir}_{\text {valley }} \mathrm{Ir}_{\text {comb }} @ \mathrm{Au}(110), E_{\text {react }}=0.76 \mathrm{eV}$, surfaces and exothermic in the case of the $\operatorname{Ir}_{\text {comb }} \mathrm{Ir}_{\text {comb }} @ \mathrm{Au}(110)$ catalyst model $\left(E_{\text {react }}=-0.25 \mathrm{eV}\right)$. The latter constitutes the single case of the considered gold surfaces doped with transition metal atoms where the reaction energy is negative. The estimated rate constants in the most favorable $\mathrm{Ir}_{2} @ \mathrm{Au}(110)$ case present high values at temperatures of $470 \mathrm{~K}$ and $600 \mathrm{~K}$, which suggests that the NO dissociation is feasible in this range of temperatures on this type of doped gold surfaces. Despite the fact that the adsorption energies for $\mathrm{NO}$ on $\mathrm{Ir}_{2, \text { comb }} @ \mathrm{Au}(110)$ and on $\mathrm{Ir}_{\text {valley }} \mathrm{Ir}_{\text {comb }} @ \mathrm{Au}(110)$ are larger than the barriers for the dissociation reaction, the very low rate constants calculated suggest that the reaction will take place just under special conditions of temperature and pressure.

The calculations for the reaction dissociation of $\mathrm{NO}$ on the Ir@Ni(110) model surface, a cheaper catalyst model, presents a low activation energy barrier $\left(E_{\text {act }}=0.41 \mathrm{eV}\right)$, which is similar to that calculated for pure $\operatorname{Ir}(110)$, and a rather negative reaction energy $\left(E_{\text {react }}=-0.85 \mathrm{eV}\right)$. These values indicate that the reaction of NO dissociation is very attractive on Ir doped $\mathrm{Ni}$ catalysts. In fact, these results support recent findings where the Ir@Ni catalysts were found to be interesting for other dissociation reactions, e.g., water dissociation, ${ }^{88} \mathrm{O}_{2}$ dissociation, ${ }^{89}$ and $\mathrm{N}_{2} \mathrm{H}_{4}$ decomposition..$^{90,91}$

\section{CONCLUSIONS}

The adsorption energy of reactants and products as well as the activation energy barrier and reaction rate constant for the NO dissociation reaction on a series of bimetallic surfaces were computed by means of periodic density functional theory calculations. It was found that the NO dissociation has similar or higher activation energy barrier on $\mathrm{Au}(111)$ and on $\mathrm{Au}(110)$ surfaces singly doped with $\mathrm{Ir}, \mathrm{Ni}, \mathrm{Rh}$, or $\mathrm{Ag}$ atoms to those on the corresponding pure gold surfaces. The comparison of the activation energy barrier values on these surfaces with the adsorption energy of the NO molecule allows us to infer that the NO dissociation is only possible on the Ir@ Au(110) surface at low pressure. Higher amounts of Ir on $\mathrm{Au}(110)$ model surface was found to lead to more reactive catalytic systems, which were found to have catalytic interesting reaction rate values at temperatures about $470 \mathrm{~K}$. For these TM-doped gold based bimetallic surfaces, the doping 
was found to have a catalytic positive effect by stabilizing the reactants (increase of the interaction energy of $\mathrm{NO}$ with the catalytic surface), which prevents NO desorption before dissociation, and by lowering the reaction energy barriers with respect to that of the parent pure gold surface. Finally, the substitution of gold by nickel as the catalyst matrix was found to provide high reactive bimetallic systems for the reaction of NO dissociation.

\section{ACKNOWLEDGMENTS}

Thanks are due to Fundação para a Ciência e Tecnologia (FCT), Lisbon, Portugal, Programme Ciência 2007, and to FEDER for financial support to REQUIMTE and to CICECO (Pest-C/EQB/LA0006/2011 and Pest-C/CTM/LA0011/2011). This work has been supported by FCT through project PTDC/QUI-QUI/117439/2010 cofinanced by Programa COMPETE. J.L.C.F. acknowledges FCT for the Grant No. SFRH/BPD/64566/2009 co-financed by the Fundo Social Europeu (FSE).

${ }^{1}$ Inventory of U.S. Greenhouse Gas Emissions and Sinks (1990-2010, April 15, 2012), see http://www.epa.gov/climatechange/ghgemissions/ usinventoryreport.html (accessed September 10, 2012).

${ }^{2}$ Regulation (EC) No 715/2007 of the European Parliament and of the Council of 20 June 2007 on type approval of motor vehicles with respect to emissions from light passenger and commercial vehicles (Euro 5 and Euro 6) and on access to vehicle repair and maintenance information, see http://eur-lex.europa.eu/LexUriServ/LexUriServ.do?uri=CELEX: 32007R0715:en:NOT (accessed September 10, 2012).

${ }^{3}$ M. Shelef and G. W. Graham, Catal. Rev. - Sci. Eng. 36, 433 (1994).

${ }^{4}$ K. C. Taylor, Catal. Rev. - Sci. Eng. 35, 457 (1993).

${ }^{5}$ B. E. Nieuwenhuys, Adv. Catal. 44, 259 (1999).

${ }^{6}$ F. Garin, Appl. Catal. A: Gen. 222, 183 (2001).

${ }^{7}$ R. Meyer, C. Lemire, S. K. Shaikhutdinov, and H.-J. Freund, Gold Bull. 37, 72 (2004).

${ }^{8}$ L. D. Li, J. J. Yu, Z. P. Hao, and Z. P. Xu, J. Phys. Chem. C 111, 10552 (2007).

${ }^{9}$ P. S. Lambrou, P. G. Savva, J. L. G. Fierro, and A. M. Efstathiou, Appl. Catal. B: Environ. 76, 375 (2007).

${ }^{10}$ M. Haneda, Pusparatu, Y. Kintaichi, I. Nakamura, M. Sasaki, T. Fujitani, and H. Hamada, J. Catal. 229, 197 (2005).

${ }^{11}$ S. Zhu, X. Wang, A. Wang, and T. Zhang, Catal. Today 131, 339 (2008).

${ }^{12}$ R. Zhu, M. Guo, X. Ci, and F. Ouyang, Catal. Commun. 9, 1184 (2008).

${ }^{13}$ M. Marwood and C. G. Vayenas, J. Catal. 170, 275 (1997).

${ }^{14}$ J. C. Chen, F. Y. Chang, and M. Y. Wey, Catal. Commun. 9, 1106 (2008).

${ }^{15}$ A. de Oliveira, I. M. Baibich, N. R. C. F. Machado, M. L. Mignoni, and S. B. C. Pergher, Catal. Today 133, 560 (2008).

${ }^{16}$ S. Hammache, L. R. Evans, E. N. Coker, and J. E. Miller, Appl. Catal. B: Environ. 78, 315 (2008).

${ }^{17}$ A. Lucas-Consuegra, F. Dorado, C. Jiménez-Borja, and J. L. Valverde, Appl. Catal. B: Environ. 78, 222 (2008).

${ }^{18}$ A. Lintanf, E. Djurado, and P. Vernoux, Solid State Ionics 178, 1998 (2008).

${ }^{19}$ I. Salem, X. Courtois, E. C. Corbos, P. Marecot, and D. Duprez, Catal. Commun. 9, 664 (2008).

${ }^{20}$ M. Casapu, J.-D. Grunwaldt, M. Maciejewski, F. Krumeich, A. Baiker, M. Wittrock, and S. Eckhoff, Appl. Catal. B: Environ. 78, 288 (2008).

${ }^{21}$ Y. Hu and K. Griffiths, Appl. Surf. Sci. 254, 1666 (2008).

${ }^{22}$ J. Xiao, X. Li, S. Deng, F. Wang, and L. Wang, Catal. Commun. 9, 563 (2008).

${ }^{23}$ X. Wang, A. Wang, X. Wang, X. Yang, and T. Zhang, Gold Bull. 40, 52 (2007).

${ }^{24}$ N. W. Cant and N. J. Ossipoff, Catal. Today 36, 125 (1997).

${ }^{25}$ S. Qiu, R. Ohnishi, and M. Ichikawa, J. Phys. Chem. 98, 2719 (1994).

${ }^{26}$ S. Qiu, R. Ohnishi, and M. Ichikawa, J. Chem. Soc., Chem. Commun. 1992, 1425 .

${ }^{27}$ Y. Shi, H. Pan, Y. Zhang, and W. Li, Catal. Commun. 9, 796 (2008).
${ }^{28}$ R. Zhang and S. Kaliaguine, Appl. Catal. B: Environ. 78, 275 (2008).

${ }^{29}$ S. P. Ramnani, S. Sabharwal, J. V. Kumar, K. H. P. Reddy, K. S. R. Rao, and P. S. S. Prasad, Catal. Commun. 9, 756 (2008).

${ }^{30}$ J. R. H. Carucci, K. Arve, K. Eränen, D. Y. Murzin, and T. Salmi, Catal. Today 133, 448 (2008).

${ }^{31}$ J. M. D. Cónsul, I. Costilla, C. E. Gigola, and I. M. Baibich, Appl. Catal. A: Gen. 339, 151 (2008).

${ }^{32}$ J. M. D. Cónsul, C. A. Peralta, J. A. C. Ruiz, H. O. Pastore, and I. M. Baibich, Catal. Today 133, 475 (2008).

${ }^{33}$ Y. Xue, G. Lu, Y. Guo, Y. Guo, Y. Wang, and Z. Zhang, Appl. Catal. B: Environ. 79, 262 (2008).

${ }^{34}$ C. He, M. Paulus, W. Chu, J. Find, J. A. Nickl, and K. Köhler, Catal. Today 131, 305 (2008).

${ }^{35}$ M. F. Irfan, J. H. Goo, and S. D. Kim, Appl. Catal. B: Environ. 78, 267 (2008).

${ }^{36}$ E. B. Silveira, C. A. C. Perez, M. A. S. Baldanza, and M. Schmal, Catal. Today 133, 555 (2008).

${ }^{37}$ Y. Shi, H. Pan, Z. Li, Y. Zhang, and W. Li, Catal. Commun. 9, 1356 (2008).

${ }^{38}$ C. D. Chang, J. G. Santiesteban, D. S. Shihabi, and S. A. Stevenson, U.S. patent 5,401,478 (28 March 1995) (to Mobil Oil Corporation).

${ }^{39}$ N. Miyoshi, S. Matsumoto, K. Katoh, T. Tanaka, J. Harada, N. Takahashi, K. Yokota, M. Suguira, and K. Kasahara, SAE Technical Paper 950809, 1995.

${ }^{40}$ S. Matsumoto, Y. Ikeda, H. Suzuki, M. Ogai, and N. Miyoshi, Appl. Catal. B: Environ. 25, 115 (2000).

${ }^{41}$ S. Roy and M. S. Hegde, Catal. Commun. 9, 811 (2008).

${ }^{42}$ S. Roy, B. Viswanath, M. S. Hegde, and G. Madras, J. Phys. Chem. C 112, 6002 (2008).

${ }^{43}$ K. Asano, C. Ohnishi, S. Iwamoto, Y. Shioya, and M. Inoue, Appl. Catal. B: Environ. 78, 242 (2008).

${ }^{44}$ M. A. Debeila, N. J. Coville, M. S. Scurrell, and G. R. Hearne, Catal. Today 72, 79 (2002).

${ }^{45}$ M. A. Debeila, N. J. Coville, M. S. Scurrell, G. R. Hearne, and M. J. Witcomb, J. Phys. Chem. B 108, 18254 (2004).

${ }^{46}$ M. A. Debeila, N. J. Coville, M. S. Scurrell, and G. R. Hearne, Appl. Catal. A: Gen. 291, 98 (2005).

${ }^{47}$ M. A. Debeila, N. J. Coville, M. S. Scurrell, and G. R. Hearne, J. Mol. Catal. A: Chem. 219, 131 (2004).

${ }^{48}$ Y. Wang, D. Zhang, Z. Yu, and C. Liu, J. Phys. Chem. C 114, 2711 (2010).

${ }^{49}$ P. Bera, K. C. Patil, V. Jayaram, M. S. Hegde, and G. N. Subbanna, J. Mater. Chem. 9, 1801 (1999).

${ }^{50}$ T. Fujitani, I. Nakamura, A. Takahashi, M. Haneda, and H. Hamada, J. Catal. 253, 139 (2008).

${ }^{51}$ T. M. Salama, R. Ohnishi, and M. Ichikawa, J. Chem. Soc., Faraday Trans. 92, 301 (1996).

${ }^{52}$ C. P. Vinod, J. W. N. Hansa, and B. E. Nieuwenhuys, Appl. Catal. A: Gen. 291, 93 (2005).

${ }^{53}$ C.-Z. He, H. Wang, P. Zhu, and J.-Y. Liu, J. Chem. Phys. 135, 204707 (2011).

${ }^{54}$ J. Rempel, J. Greeley, L. B. Hansen, O. H. Nielsen, J. K. Nørskov, and M. Mavrikakis, J. Phys. Chem. C 113, 20623 (2009).

${ }^{55}$ D. Loffreda, F. Delbecq, D. Simon, and P. Sautet, J. Chem. Phys. 115, 8101 (2001)

${ }^{56}$ D. Loffreda, D. Simon, and P. Sautet, J. Catal. 213, 211 (2003).

${ }^{57}$ J. L. C. Fajín, M. N. D. S. Cordeiro, and J. R. B. Gomes, J. Phys. Chem. C 113, 8864 (2009).

${ }^{58}$ L. Ilieva, G. Pantaleo, J. W. Sobczak, I. Ivanov, A. M. Venezia, and D. Andreeva, Appl. Catal. B: Environ. 76, 107 (2007).

${ }^{59}$ L. Ilieva, G. Pantaleo, R. Nedyalkova, J. W. Sobczak, W. Lisowski, M. Kantcheva, A. M. Venezia, and D. Andreeva, Appl. Catal. B: Environ. 90, 286 (2009).

${ }^{60}$ B. Hammer, Faraday Discuss. 110, 323 (1998).

${ }^{61}$ B. Hammer, J. Catal. 199, 171 (2001).

${ }^{62}$ B. Hammer, Surf. Sci. 459, 323 (2000).

${ }^{63}$ Q. Ge and M. Neurock, J. Am. Chem. Soc. 126, 1551 (2004).

${ }^{64}$ S. González, D. Loffreda, P. Sautet, and F. Illas, J. Phys. Chem. C 111, 11376 (2007).

${ }^{65}$ L. Olsson, V. P. Zhdanov, and B. Kasemo, Surf. Sci. 529, 338 (2003).

${ }^{66} \mathrm{~L}$. Olsson and B. Andersson, Top. Catal. 28, 89 (2004).

${ }^{67}$ H. Sakurai, S. Tsubota, and M. Haruta, Appl. Catal. A 102, 125 (1993).

${ }^{68}$ J. L. C. Fajín, M. N. D. S. Cordeiro, and J. R. B. Gomes, J. Catal. 289, 11 (2012).

${ }^{69}$ W. Chen, A. L. Stottlemyer, J. G. Chen, P. Kaghazchi, T. Jacob, T. E. Madey, and R. A. Bartynski, Surf. Sci. 603, 3136 (2009). 
${ }^{70}$ D. F. Remar, A. M. Turiev, N. I. Tsidaeva, and T. T. Magkoev, Russ. Phys. J. 53, 480 (2010).

${ }^{71}$ J. L. C. Fajín, M. N. D. S. Cordeiro, and J. R. B. Gomes, Chem. Commun. 47, 8403-8405 (2011)

${ }^{72}$ J. L. C. Fajín, M. N. D. S. Cordeiro, F. Illas, and J. R. B. Gomes, J. Catal. 276, 92 (2010).

${ }^{73}$ A. M. Pessoa, J. L. C. Fajín, J. R. B. Gomes, and M. N. D. S. Cordeiro, J. Mol. Struct.: THEOCHEM 946, 43 (2010).

${ }^{74}$ J. L. C. Fajín, M. N. D. S. Cordeiro, and J. R. B. Gomes, J. Phys. Chem. C 111, 17311 (2007).

${ }^{75}$ D. Tomanék, S. Mukherjee, V. Kumar, and K. H. Bennemann, Surf. Sci. 114, 11 (1982).

${ }^{76}$ D. D. Beck, C. L. DiMaggio, and G. B. Fisher, Surf. Sci. 297, 293 (1993).

${ }^{77}$ A. Christensen, A. V. Ruban, P. Stoltze, K. W. Jacobsen, H. L. Skriver, J. K. Nørskov, and F. Besenbacher, Phys. Rev. B 56, 5822 (1997).

${ }^{78}$ G. Kresse and J. Hafner, Phys. Rev. B 47, 558 (1993).

${ }^{79}$ G. Kresse and J. Furthmüller, Comput. Mater. Sci. 6, 15 (1996).

${ }^{80}$ G. Kresse and J. Furthmüller, Phys. Rev. B 54, 11169 (1996).
${ }^{81}$ J. P. Perdew, J. A. Chevary, S. H. Vosko, K. A. Jackson, M. R. Pederson, D. J. Singh, and C. Fiolhais, Phys. Rev. B 46, 6671 (1992).

${ }^{82}$ P. E. Blöchl, Phys. Rev. B 50, 17953 (1994).

${ }^{83}$ G. Kresse and D. Joubert, Phys. Rev. B 59, 1758 (1999).

${ }^{84}$ H. J. Monkhorst and J. D. Pack,Phys. Rev. B 13, 5188 (1976).

${ }^{85}$ G. Henkelman and H. Jónsson, J. Chem. Phys. 111, 7010 (1999).

${ }^{86}$ K. J. Laidler, Chemical Kinetics, 3rd ed. (Harper Collins, New York, 1987), p. 193.

${ }^{87}$ J. L. C. Fajín, M. N. D. S. Cordeiro, and J. R. B. Gomes, Chem. Phys. Lett. 503, 129 (2011).

${ }^{88}$ J. L. C. Fajín, M. N. D. S. Cordeiro, and J. R. B. Gomes, J. Phys. Chem. C 116, 10120 (2012).

${ }^{89}$ J. L. C. Fajín, M. N. D. S. Cordeiro, and J. R. B. Gomes, "DFT study on the reaction of $\mathrm{O}_{2}$ dissociation catalyzed by gold surfaces doped with transition metal atoms," Appl. Catal. A: Gen. (submitted).

${ }^{90}$ C. Cakanyildirim, U. B. Demirci, T. Sener, Q. Xu, and P. Miele, Int. J. Hydrogen Energy 37, 9722 (2012).

${ }^{91}$ S. K. Singh and Q. Xu, Chem. Commun. 46, 6545 (2010). 